The Geneva Papers on Risk and Insurance, 19 (No. 72, July 1994) 357-364

\title{
The Need for Insurers to Change
}

\author{
by Dean O'Hare*
}

\section{Introduction}

The insurance industry has entered what will likely be the most interesting and change-filled period in its long history. Our collective ability as an industry to cope with this change is critical to maintaining the confidence of our customers and ensuring that insurance is indeed a "long-term proposition".

The long view is one that is all too seldom taken these days, at least in the United States, where my company is based. The tendency of investors to focus on quarterly earnings or executives to be motivated by annual incentives can cause us to overlook periodic reminders of our vulnerability if we do not manage our affairs properly. We have had several such reminders recently, including massive and rising environmental exposures, the related problems of Lloyd's and the multiple catastrophes of the last few years. At the same time, we are seeing fundamental shifts in the nature of our markets, complete reevaluation by customers of their relationships with insurers, and the advent of some fearsome new competitors.

Against this backdrop, the opportunity to step back and examine the major trends at work in our industry and what we need to do to address them is welcomed. This examination will be done from the perspective of the chief executive officer of a large U.S.based property and casualty insurer that writes business worldwide. The focus will be on the property and casualty industry with particular attention to the U.S. marketplace, although much of what will be discussed holds true for U.S. life and health insurers and overseas insurers as well.

\section{The changing landscape}

Any discussion of change in the financial services sector must start with globalization. Few barriers remain to the movement of money, information and ideas across borders, and these are the three currencies in which we do business. Moreover, among our customers, there are few companies of any size today that have not at least considered markets outside of their home countries. Those that have expanded internationally need capital, protection and advice. Our industry is one they look to for this assistance. Because of the enormous size of our own domestic market, we in the U.S. insurance industry may be

* Chairman and Chief Executive Officer, The Chubb Corporation, Warren, New Jersey/USA. Paper presented at the 30th Annual Seminar of the International Insurance Society, Madrid, June 19-23, 1994. 
among the last to commit major resources beyond our own borders. But, just as insurers from Europe and the Far East are staking their claim on our shores, we are moving abroad as well. For example, Chubb has set a goal of deriving 25 percent of its revenues from outside of North America by the year 2000 .

The make-up of our competition is changing. Insurance is no longer the sole province of traditional insurers; other financial service giants have determined that we are not doing an adequate job of fully serving our customers and that there is room for them in our business. The phenomenon known as "bancassurance" and "allfinanz", already well established in Europe, will become increasingly prevalent in other parts of the world. Companies such as Marsh \& McLennan and Morgan Guaranty are moving aggressively to gain a foothold in the insurance underwriting business through controlled distribution and strategic alliances. The Bermuda off-shore captives have raised a huge amount of capital, which is likely to find its way into the primary markets of the United States. Firms such as General Electric of the United States believe that they can fill a void and deliver traditional and non-traditional products faster, cheaper and more directly than their competition. The entry of such companies has vast implications for how we work, for the products and services we offer and for how we interrelate with our customers.

The third factor shaping the landscape is the world economy. There is little doubt that in most of the developed countries we are emerging from recession, but that the foreseeable future will likely be characterized by at best slow growth. Managements in all industries are focussing on costs. The manifestations of this are everywhere. According to one survey, U.S. corporations cut an average of 3,100 jobs a day during the first quarter of this year. In Japan, companies and employees alike are struggling with the breakdown of the concept of a "job for life". Throughout Europe, companies are retrenching and governments have embarked on huge privatization programs, partly based on the recognition that the private sector can achieve greater efficiencies. For those of us in the service sector, the message should be clear: cost will be an increasingly important factor in corporate decisions, and customers will look more and more to suppliers who can provide a service or range of services most efficiently.

\section{Changing customer needs}

Our industry is constantly assessing the regulatory, economic and financial landscapes. We spend precious little time assessing the landscape of our customers and the economic, social and political problems they are facing. We need to redirect our efforts, because these problems define their protection needs and therefore our future opportunities.

The insurance industry historically has been product driven. We have done an excellent job of developing new products, coverages and packages of coverages, which we have taken to our customers and told them, "you need this". Much of the time, they agreed with us.

This relationship is changing, however. In an uncertain economy - and a soft insurance market - many customers have seen fit to re-evaluate the way they interact with their insurers. The smart insurers have picked up on this change. They are listening to their customers. They then are finding ways to address customers' problems and to identify new customer needs. It may sound simplistic, but listening to customers and understanding their problems in detail will prove to be our most important strategic activity. 
What are the customers saying? That they are tired of the status quo. They don't want the products we think they need; they want the first-class, customized service that they receive from their banks and financial advisers. They are looking for insurance companies to be partners not adversaries, and they do not want to be treated in a fragmented, shortsighted manner. Customers want us to know their business and to provide solutions that are tailored to their specific and individual needs. They are tired of our inefficiencies being passed on to them as higher costs. And they hate renewal time, which they equate with paying taxes. In short, customers are challenging us to find more creative ways to do business.

Fortunately for us, the shortcomings that customers cite do not represent multiple problems. Rather, they are the manifestations of a misguided approach. All too often, we try to fit customers into our systems. They are asking us to learn to tailor what we do well to fit their needs.

Many of the problems customers face are ones with which we truly can help. For example:

- Time and complexity. Like every business, our customers need to stay competitive by getting more things done in less and less time. At the same time, the tasks have become more complicated. To the extent that we cause them to spend any more time than absolutely necessary assessing exposure, handling legal and administrative issues, and sorting through the onslaught of confusing, often poorly conveyed information, we are not being helpful.

- Coverage cost and availability. Customers are having to pay the high costs of doing business in a litigious society, which raises the rates for insuring everything from cars to hazardous exposures. In some areas, particularly those visited by major catastrophes in the last few years, customers are worried about continued availability. These problems are most prevalent in the United States, but they are occurring in other countries as well.

- Customer expectations. Customers want us to adapt our organizations and capabilities to meet their needs. They want to be communicated with clearly and consistently, and they want to establish lasting relationships with their insurers.

- Carrier capability. Customers want to be insured by companies which are financially stable and offer high-quality products and service. In the last few years, we have seen a flight to quality in the United States, as customers have moved their business to insurers with demonstrable financial solidity. At the same time, we have seen insurance companies that have overexpanded cut back their activities to areas of traditional strength.

\section{Meeting customer needs : core business focus}

Successful insurers in the years ahead will to two things well : 1) they will expand their core businesses, building on what they know how to do well, and 2) they will learn to structure very different relationships with customers than they have in the past.

Specialized marketers have an inherent advantage over companies with multiple lines of business: they can more easily know their customers and concentrate on areas in which they can provide expert, value-added advice, guidance and products. Companies that try to be all things to all people rely more on standardized approaches. They are not geared to meeting the needs of customers looking for tailored service.

Being specialty focussed does not - in fact, it should not - limit one's horizons. Insurers must develop or acquire the capabilities to offer customers broad protection, including 
traditional property and casualty insurance, life and health insurance, and investment tools to help protect and build customers' financial strength. In doing so, insurers must build on what they know while not abandoning their core philosophies, goals and strategies.

Insurers that take a specialty approach need not be small. In fact, large companies that can realize economies of scale have a distinct advantage. They can offer a variety of products within a particular market segment, taking advantage of their size and market penetration to achieve economies and to cross-market their services. For example, take a company that identifies its market as high-net asset individuals. If it can find a way to address all of these individuals' asset protection needs - from property insurance to insurance for their collections to life products to an array of investment vehicles - the insured reaps the benefits of an in-depth, long-term, multi-faceted relationship. The customer has the ease of dealing with one provider of multiple services, and both potentially save from the efficiency of lower transaction costs.

As customers' needs become more complex, they require increasingly sophisticated responses on the part of insurers. This sophistication, in turn, requires in-depth knowledge and experience of different markets and risks, expertise that often only a specialty provider can develop. Chubb, for example, has carved out a successful niche in directors and officers liability insurance. This started in the 1970 s as a small business for us; it is now one of the largest and most successful lines we have.

At the moment, the United States is probably the leading market for such sophisticated coverages, owing primarily to our litigious history and legal system. However, the needs in other countries are becoming more complex over time. Chubb is now writing significant volumes of directors and officers coverage in the UK, for example. This trend is likely to continue to the benefit of specialty carriers.

Specialized insurers have to be more creative and nimble than their multi-line counterparts in how they handle large customers with multiple needs. Such customers increasingly have risks that fall outside an insurer's chosen specialties or that cannot be underwritten profitably or cost-effectively. More and more today, big customers are cutting costs by retaining risks, which they do not necessarily know how to manage.

These situations offer real opportunities for insurers who can step outside of their instinctive underwriting mindset and approach them instead as consultants or advisors. A big part of our future is lending our expertise to customers looking for innovative ways to handle risks. We may not underwrite the risk ourselves, but we can use our experience to find other, potentially non-traditional solutions. We can charge a fee for our help and maintain and add depth to our customer relationships.

\section{Meeting customer needs: structuring the relationship}

As an industry, we have not done an effective job of structuring our relationships with our customers. The insurance process is riddled with waste and inefficiency. This is one of the biggest areas of change we face. Before we can address the customer concerns cited earlier, we must build an organizational framework that enables us to work with our customers more efficiently and productively.

The first step is to put decision-makers in front of customers. We too often make customers talk to multiple underwriters for their various needs and do our best to obscure from 
them who the ultimate decision-makers are in the organization. It is no surprise that we appear to many as large, faceless bureaucracies in which no individual is held accountable for addressing a customer's needs. Streamlining our customer contact and making our underwriters more accessible to clients can reduce the internal cost of transactions by up to 25 percent. It will also reduce the number of layers in our organizations and force quicker responses. We will make fewer mistakes in the translation from broker to underwriter and ultimately provide greater value and satisfaction. All of this should mean greater retention and growth and, potentially, lower costs. We need only look outside our own industry for examples of how companies like Johnson \& Johnson, General Electric and AT\& T are structuring their customer relationships along these lines.

We also need to rethink the structure of the insurance transaction. This goes to the heart of the "time and complexity" problem cited earlier. A recent study by the management consulting firm McKinsey \& Co. stated: "The customers do not care whether the underwriter, insurance clerk or agent completes the endorsement form; they just want a quick and accurate response". Customers spend more time gathering information and telling and retelling their stories to brokers and carriers than they spend assessing exposures, conducting cash flow studies and managing risk. If the industry truly wants to provide value to customers, it will develop an exposure-based customer assimilation process that would ease the pain of placing and renewing business.

The banking industry provides us with a model to follow. Unlike insurers, banks do not require annual renewals of checking or savings accounts. If you have a large account balance, most banks provide personalized service like trust service or private banking.

These kinds of relationships should be developed in all sectors of the insurance world, helping significant customers through value-added services and minimizing account administration. Imagine the impact if a company with 500,000 policies decides with its customers to create an efficient relationship with no annual renewals. Interactive technology is used to process changes in exposures, report losses, communicate general information and create efficiencies for both clients and carrier. In place of annual renewals is a simple contract entered into at the start of the relationship laying out terms, conditions and price. The price is adjusted annually as necessary, but no renewal forms are sent. Rather, both parties operate under the assumption that the relationship will continue indefinitely, with the proviso that either can terminate it with 60 days notice. What this describes, of course, is the kind of relationship most other service firms have with their clients. Why won't it work in insurance? Our customers would have more time to focus on pressing issues, and carriers and producers would have more time to sell other services to their customers, creating efficient strategic alliances, assessing risk, tracking information and minimizing future losses.

In addressing how we interact with our customers, we also need to confront the issue of distribution. While brokers and agents bring value to many, if not most, relationships, there is no denying that the insurance distribution system is inherently inefficient. As with all inefficiencies, there is an associated cost which either the client or the insurer pays for. This is one of the most difficult challenges we face as an industry, and the solution will be neither simple nor quick. We need to begin work now with customers and brokers alike to address this issue, since maintaining the status quo puts us at a competitive disadvantage to alternative providers. 


\section{Insurance as a long-term proposition}

Whatever we do to focus our businesses and enhance our customer relationships will come to naught if we do not maintain our financial integrity. The recent catastrophe-related insolvencies of life/health and property/casualty insurers underline how much of the industry, particularly in the United States, has strayed from our reason for being - to provide security. Disregarding our raison d'être, as too many insurers have done in the last few years by cutting prices and making risky investments, has created much policyholder ill-will and regulatory pressure.

It is tempting to look at solvency as primarily a U.S. issue. Many of the weakest insurers are, and have been, U.S.-based. Our European colleagues generally have taken a longer-term view and, assisted somewhat by their tax laws, have built formidable financial strength.

The last five years or so have seen the solvency of financial institutions emerge as an issue of more international concern, however, as long-tail environmental and other liability policies have undermined the very foundations of Lloyd's and led to other insolvencies in the London market. The idea of insurance as a social safety net for the private sector is a seductive one for politicians and judges alike, regardless of nationality. It is also a dangerous one for our industry as some of us know from painful experience. Last August, Chubb and another insurer, CNA, committed to pay over $\$ 3$ billion to resolve asbestos claims against two 35-year-old general liability policies written at a time when even the most clairvoyant of underwriters could not have foreseen such an exposure for a product then thought to be safe. To quote an article from the International Herald Tribune in early April, "There is no safe place to be an insurance company today".

That being the case, it is more important than ever that we who plan to be in the business for the long term err on the side of financial prudence. One reason Chubb could take its share of the $\$ 3$ billion asbestos hit and still maintain the top-most ratings with Best, Moody's and Standard \& Poor's is that we have long followed such a policy.

It would also help to ensure our long-term viability if, as an industry, we could move closer to underwriting profitability. Few insurers even have this as a goal, with the predictable result that the U.S. industry's combined ratio of 106.9 in 1993 was its best since recording a 104.6 in 1987. In a low interest rate but highly uncertain economic environment, surviving on investment income is an increasingly difficult proposition.

\section{Catastrophes add urgency}

The last few years have underscored the urgent need to build and implement wellconceived catastrophe management strategies. Four of the five most severe individual catastrophes in the second half of this century have occurred since 1989. Despite only one small hurricane in 1993 (Emily at $\$ 30$ million), the U.S. insurance industry suffered an estimated $\$ 6$ billion in catastrophe losses last year primarily from winter storms, the World Trade Center bombing and the California brush fires. 1993 was the third worst catastrophe year on record after 1992, which totalled $\$ 20$ billion, and 1989 , when Hurricane Hugo and the Loma Prieta Earthquake struck. 1994 is not off to a good start as damage from the California earthquake and a severe winter have already added up to an estimated $\$ 7$ billion. 
The problem is not just Mother Nature. Demographic shifts have resulted in more densely populated catastrophe-prone areas over the last ten years, and property values have increased substantially on individual structures over this same period. For example, from 1970 to 1990, the population of the Atlantic coast in the Southeastern United States rose 75 percent, and Southern California witnessed a similar population increase, compared with only a 20 percent increase in the United States as a whole.

These areas are at great risk for future disasters. Industry estimates for a major hurricane or earthquake striking a populous area such as Miami-Ft. Lauderdale, Florida, or Los Angeles County, California, are $\$ 50$ billion in insured damage, or approximately 30 percent of estimated industry surplus.

In the United States, infrastructure development has lagged demographic shifts. Welldeveloped older areas especially suffer from weakened or crumbling infrastructure. In addition, replacement costs on both residential and commercial structures are not being quantified properly for a number of reasons, including a lack of industry discipline before major disasters hit and regulatory/consumer exaggerations of claims after losses occur.

The reinsurance landscape also has changed. There are now fewer traditional reinsurers, and there was less reinsurance capacity available during 1993. Pricing has dramatically increased on catastrophe covers where we have seen 30 percent to 300 percent rate increases. Internal company retentions have doubled and tripled from $\$ 50$ million to $\$ 100$ million or more. Some new reinsurance products have reached the market, but reinstatements are now restricted, and treaty exclusions have been added. Primary companies have elected, or been forced, not to place 100 percent orders and have become large self-insurers of catastrophe risks as a result. Bermuda start-ups and new offshore catastrophe capacity fill a void, but only on similarly restrictive terms.

Many insurers have business that is too concentrated in high-catastrophe areas. Allstate estimated that its losses from Hurricane Andrew exceeded all the profits from all of its business in Florida in the last 53 years. This is a difficult problem to resolve. In addition to the risk management complexities, we're dealing with a regulatory and consumer environment that is politically charged and confused. Among the solutions under discussion are a federal solvency standard and/or government backed reinsurance. A Florida state catastrophe pool was formed recently; Texas and California are examining similar facilities.

The increased frequency of catastrophes requires that we improve our underwriting skills not only for specific risks, but also for entire geographic areas. The challenge will be to manage this exposure and still remain responsive to customer needs and regulatory requirements. The process will be neither easy nor painless. But, this issue must be addressed immediately because we cannot compromise with events that have the potential to seriously damage our capital resources.

Finally, the long-term health of our industry requires continued strong competition. Nothing else can ensure that customers continue to have available markets and affordable rates. There are still too many regulatory restrictions that interfere with this goal. For example, it is inefficient and ultimately counterproductive to require an overseas company doing business in the United States to have do deal with 50 separate regulatory bodies. It is also an unfair barrier to entry which only serves to encourage overseas jurisdictions to erect barriers for U.S. companies. 
There is a need today for rational federal regulation in the U.S. that removes barriers to the free flow of capital, supports the solvency of the industry and eliminates duplicative, sometimes conflicting, regulations that compel expensive and unnecessary compliance efforts.

\section{Conclusion}

We have our work cut out for us. Insurance companies cannot merely react to the changing world around us. We must find ways to address our customers' needs, to capitalize on areas in which we can provide customers with added value, and to innovate. Success requires a willingness not only to cope with, but to embrace change. For those willing to accept this challenge, the remainder of the 20 th century will be a very interesting time in our industry. 